\section{TRNDing toward translation}

\section{By Chris Cain, Staff Writer}

Following two years of funding pilot partnerships, the NIH's Therapeutics for Rare \& Neglected Diseases program has announced its first round of competitively awarded projects. The awards to three biotechs and an academic team illustrate the tack NIH is taking to advance a range of small molecules into the clinic.

NIH launched the TRND program in May 2009 as a \$24 million project to advance the preclinical development of lead compounds for rare and neglected diseases. A rare disease is defined as affecting fewer than 200,000 people in the U.S. Neglected diseases are not strictly defined, but the NIH describes them on the website for the National Human Genome Research Institute as "conditions that inflict severe health burdens on the world's poorest people."

Over the last two years, TRND has started five pilot projects to determine how to best administer the program (see Table 1, "TRND partnerships: pilot projects"). The projects were initiated by TRND to provide test cases in which the NIH would work out the logistics of funding, organizing and conducting the preclinical work needed to develop compounds.

One example of a pilot project is the partnership with AesRx LLC to conduct the preclinical work needed to file an IND for Aes-103, a new treatment for sickle cell disease. ${ }^{1}$ Another is its collaboration with the Leukemia \& Lymphoma Society, the University of Kansas Medical Center and the National Heart, Lung, and Blood Institute to repurpose the approved arthritic drug auranofin for chronic lymphocytic leukemia (CLL).

Christopher Austin, scientific director of the NIH Center for Translational Therapeutics (NCTT), said TRND chose pilot projects that reflect a range of possible partnership and development scenarios, including optimizing lead compounds, repurposing existing compounds and preparing an IND package after selecting a clinical candidate.

"If you look at pilot projects-one is strictly academic, two are with biotechs and two are with a combination of disease foundations and NIH investigators. We've got all flavors," said Austin.

This year, TRND was made part of the NCTT with a $\$ 24$ million budget, though the program has not disclosed how much it allocates on a per-project basis.

Although TRND is still working with its pilot partners, the initiative has now selected an additional 4 partners from the 63 applications it received as part of its first competitive call for applications (see Table 1, “TRND partnerships: first round of solicited projects").

\begin{tabular}{|c|c|c|c|}
\hline Company/institutional partners & Compound & Target/mechanism & Indication \\
\hline $\begin{array}{l}\text { New Zealand Pharmaceuticals Ltd./National } \\
\text { Human Genome Research Institute }\end{array}$ & $\begin{array}{l}\text { N-Acetyl-D-mannosamine } \\
\text { (ManNAc) }\end{array}$ & Corrects sialic acid deficiency & $\begin{array}{l}\text { Hereditary inclusion body myopathy } \\
\text { (hIBM) }\end{array}$ \\
\hline $\begin{array}{l}\text { Various Niemann-Pick disease type C } \\
\text { foundations/Washington University in St. } \\
\text { Louis/Albert Einstein College of Medicine of } \\
\text { Yeshiva University }\end{array}$ & $\begin{array}{l}\text { 2-Hydroxypropyl- } \beta \text {-cyclodextrin } \\
\text { (HPBCD) }\end{array}$ & $\begin{array}{l}\text { Decreases cholesterol and } \\
\text { sphingolipid storage }\end{array}$ & $\begin{array}{l}\text { Niemann-Pick disease type } \mathrm{C} 1 \\
\text { (NPC1) }\end{array}$ \\
\hline $\begin{array}{l}\text { NIH Chemical Genomics Center/Rush } \\
\text { University Medical Center/Yale University }\end{array}$ & Oxadiazole 2-oxides & $\begin{array}{l}\text { Inhibits schistosome redox } \\
\text { pathways }\end{array}$ & $\begin{array}{l}\text { Schistosomiasis and hookworm } \\
\text { disease }\end{array}$ \\
\hline ReveraGen BioPharma Inc. & VBP15 & $\begin{array}{l}\text { Modified glucocorticoid with } \\
\text { reduced side effects }\end{array}$ & $\begin{array}{l}\text { Duchenne muscular dystrophy } \\
\text { (DMD) }\end{array}$ \\
\hline Viamet Pharmaceuticals Inc. & VT-1129 & $\begin{array}{l}\text { Cytochrome P450 C- } 14 \\
\alpha \text {-demethylase (CYP51) inhibitor }\end{array}$ & Cryptococcal meningitis \\
\hline National Human Genome Research Institute & Not applicable & $\begin{array}{l}\text { Inhibitor of core binding factor } \\
\text { (CBF) protein interactions }\end{array}$ & $\begin{array}{l}\text { CBF-driven acute myelogenous } \\
\text { leukemia (AML) and acute } \\
\text { lymphoblastic leukemia (ALL) }\end{array}$ \\
\hline
\end{tabular}


"Half of the applications were from academics and half were from companies and nonprofits," said Austin.

He emphasized, "Some of these will be public-private partnerships in the truest sense-the TRND model is not a funding vehicle. We form joint project teams with the groups who are selected, and that project team decides where they will go."

Austin contrasted this with a grant program, in which the funding agency has comparatively little input once the funds have been awarded.

\section{Neglected disease, neglected compound}

Viamet Pharmaceuticals Inc.'s VT-1129 is being developed with TRND to treat cryptococcal meningitis, a neglected disease that affects about one million people a year-predominantly HIV-infected, immunocompromised patients in sub-Saharan Africa. About 500,000 people die annually due to lack of effective treatment, which typically requires extended treatment with i.v. antifungals.

VT-1129 is an oral inhibitor of cytochrome P450 C-14 $\alpha$-demethylase (CYP51).

"We have formed a joint development team, and TRND has several people on their end involved. We work on the action items together, and ultimately they will contract with vendors needed to get the preIND work done and pay for that work," said Viamet president and CEO Robert Schotzinger.

He added, "As opposed to other government-type relationships, we don't receive a grant; TRND independently pays for these activities."

VT-1129 was discovered while Viamet was screening and characterizing small molecule CYP51 inhibitors as potential antifungal agents. "VT-1129 is one of the most potent compounds against cryptococcal strains that we have ever seen, and it behaves very well in animal models we think because of its CNS penetration," Schotzinger told SciBX.

However, the compound was ultimately shelved in favor of VT-1161, another CYP51 inhibitor. "VT-1161 behaves better than VT-1129 in Candida infections, which is a lucrative space for us, so it became our lead Phase I program," said Schotzinger.

"The unfortunate reality for small or large companies in the U.S. is that it is hard to financially justify a program to treat cryptococcal meningitis, which is not a significant problem in developed countries. The bottom line is that the TRND partnership allows us to move a compound forward to meet a significant unmet medical need in sub-Saharan Africa and Southeast Asia that would otherwise not have been developed."

\section{Rare indication on a budget}

Afraxis Inc. has partnered with TRND to identify and prepare an IND to move a 21 protein (Cdc42 Rac)-activated kinase 1 (PAK1) inhibitor into the clinic to treat Fragile $\mathrm{X}$ syndrome. ${ }^{2}$ The Orphan disease is the most common inherited form of mental retardation and the most common cause of autism. It affects about 1 in 3,600 males and 1 in 4,000-6,000 females.

Jay Lichter, CEO of Afraxis and a managing director of Avalon Ventures, told SciBX the TRND partnership would allow Afraxis to spend more time optimizing lead candidates before moving forward with IND-enabling studies.

Avalon Ventures was the sole investor in Afraxis' undisclosed series A round in 2007.
Lichter said the company had established a budget to ensure enough money was left to do the toxicology that would be required to identify a partner or investor for a lead compound.

"We may have had to select something that was promising but not ideal. Now we can take a little more time," he said.

Lichter emphasized that Afraxis' Fragile X program was chosen by TRND because the early data are compelling, the target is of high interest and the company has a very good understanding of the SAR around the target.

He added that the company now can take some of the resources it had been applying to the Fragile X program and apply
"TRND really thought this through. Anything prior to the collaboration is ours; anything we invent solely remains ours; anything we invent jointly is joint ownership; and anything they invent we have the option to exclusively license. They don't want to be an encumbrance to companies."

- Jay Lichter, Afraxis Inc. them to a second program in neurofibromatosis. "Now we can develop two sets of compounds, one for Fragile X, a nonlethal CNS disorder, and one for neurofibromatosis," which is a lethal cancer characterized by uncontrolled intracranial tumor growth, he said.

In terms of IP, Lichter told SciBX that "TRND really thought this through. Anything prior to the collaboration is ours; anything we invent solely remains ours; anything we invent jointly is joint ownership; and anything they invent we have the option to exclusively license. They don't want to be an encumbrance to companies."

The third and fourth partnerships include a project from ReveraGen BioPharma Inc. to develop modified glucocorticoids with reduced side effects for Duchenne muscular dystrophy (DMD) and an NIH project to optimize a lead compound for the development of a subgroup of patients with acute myelogenous leukemia (AML) and acute lymphoblastic leukemia (ALL).

ReveraGen and current TRND director John McKew could not be reached for comment.

TRND is reviewing its second round of applications and expects to open a third round this fall.

Cain, C. SciBX 4(40); doi:10.1038/scibx.2011.1105

Published online Oct. 13, 2011

\section{REFERENCES}

1. Usdin, S. SciBX 3(48); doi:10.1038/scibx.2010.1430

2. Bouchie, A. BioCentury 18(18), A11; April 19, 2010

\section{COMPANIES AND INSTITUTIONS MENTIONED}

AesRx LLC, Newton, Mass.

Afraxis Inc., La Jolla, Calif.

Avalon Ventures, La Jolla, Calif.

Leukemia \& Lymphoma Society, White Plains, N.Y.

National Institutes of Health, Bethesda, Md.

National Heart, Lung, and Blood Institute, Bethesda, Md.

National Human Genome Research Institute, Bethesda, Md.

NIH Center for Translational Therapeutics, Bethesda, Md.

ReveraGen BioPharma Inc., Rockville, Md.

University of Kansas Medical Center, Kansas City, Kan.

Viamet Pharmaceuticals Inc., Morrisville, N.C. 